\title{
Overcoming Extreme Poverty in India: Lessons Learnt from SKS
}

\author{
Karishma Huda
}

\begin{abstract}
Swayam Krishi Sangam (SKS), a leading microfinance institution in India, has implemented an innovative approach to poverty reduction known as the Ultra Poor Program (UPP). SKS believes that income generation is the key to breaking the cycle of poverty, but that the poorest are too vulnerable, too risk adverse and lack the entrepreneurial skills to make use of a microfinance loan. SKS therefore offers carefully targeted individuals with productive assets, close accompaniment, a cash stipend, a savings scheme and health services for 18 months, in order to 'graduate' them out of extreme poverty. The remit is to provide social safety nets with an effective 'exit' strategy, with particular attention to the challenge of scaling-up nationally.
\end{abstract}

\section{Introduction}

The first part of the article argues that the poorest have traditionally been excluded from conventional poverty alleviation programmes. This, in turn, opened up a space for civil society organisations, such as the Bangladesh Rural Advancement Committee (BRAC) in Bangladesh, to think creatively about how to bring the most marginalised into the folds of their mainstream development interventions. The positive results from BRAC's Targeting Ultra Poor (TUP) experiment inspired organisations globally to try and test the BRAC model in their contexts.

The second part of the article delves into the process evaluation findings from one such adaptation - Swayam Krishi Sangam (SKS) Foundation's Ultra Poor pilot programme (UPP) in Andhra Pradesh, India. Specifically, it discusses the challenges of scaling a pilot into a nation-wide programme - can the successes be transferred, and how important is state engagement in reaching the masses and sustaining these results?

\subsection{Excluding the poorest}

A large body of work has pointed to the fact that conventional development interventions, namely state-run programmes and microfinance interventions, have traditionally bypassed or actively excluded the most vulnerable. This includes extremely poor and female-headed households (although in the context of India, these are generally one and the same).

Government programmes have faced a number of challenges in reaching the most vulnerable. First, they operate on such a large scale that it is difficult to implement targeting tools that capture the various nuances in poverty levels. Given that extremely vulnerable households are generally unaware of how to apply for government services and are often unregistered, adds to their likelihood of being bypassed. Second, state interventions do not generally lack the ability to tackle the complex web of deprivations that affect extremely poor households. State programmes, such as wage employment or the provision of productive assets, assume that the income boost alone will help households 'escape' poverty as a one-step process. Alternatively, they provide food rations or other forms of one-off assistance that can only help them smooth consumption when they face a temporary shock. Lastly, local level bureaucracy, inefficiency and corruption that characterise state interventions work against the poorest. Interviews with extremely poor people in Andhra Pradesh revealed a grave mistrust towards government officials for the clandestine ways they make decisions about to whom to distribute pro-poor services.

The poorest are not the ones who get the BPL card. Those who have autos and bikes receive our rations.

IDS Bulletin Volume 41 Number 4 July 2010 (c) 2010 The Author. Journal compilation (c Institute of Development Studies Published by Blackwell Publishing Ltd, 9600 Garsington Road, Oxford OX4 2DQ, UK and 350 Main Street, Malden, MA 02148, USA 
The government officials meet at the weekly market and they tell secrets - secrets of whom they will give things to. We have no way of knowing.

This lack of transparency in targeting opens up avenues for corruption and rent-seeking:

I applied 3 times and never received a BPL [Below Poverty Line] card. I begged, did not eat, and bribed them with 300INR. Still I have received nothing, just empty promises.

Existing literature reinforces the above points. Mooji (2003) states that in Andhra Pradesh, the government intended to be more 'simple, moral, accountable, responsive and transparent (SMART)' in state-wide development initiatives. But in reality, their Participatory Irrigation Management scheme, which aimed to decentralise decision-making power to local farmers and water users, was in-fact co-opted by wealthy landlords, upper castes, and better educated people affiliated with a political party. Participation of women and 'weaker sections' of society in decision-making was negligible (Mooji 2003). Pellissery (2005) argues that anti-poverty programmes in the state of Maharashtra have deficits in their implementation. They strengthen local elites' capacity to wield power and support their own private interests, as excluding the poorest from income generating schemes enables the local elite to 'avail cheap and instant labour for their private works' (Pellissery 2005: 2).

Microfinance, another widely implemented development intervention across South Asia, did target women specifically - but excluded extremely poor women, for which various reasons have been put forth. These include group-exclusion, where the moderate poor do not accept the extreme poor into their lending groups; and self-exclusion, where rigid repayment structures and the emphasis on borrowing discourage the extreme poor from wanting to join microfinance programmes (Hashemi 1997; Rahman and Razzaque 2000). Studies also show that the poorest do not benefit even if they do join microfinance, as they do not enter with existing enterprises (Banerjee, Duflo, Glennerster and Kinnan 2009). They thus earn fewer profits, and are more likely to be inactive members that frequently enter and exit. A review of studies on government and nongovernment credit programmes in India noted systematic evidence of exclusion of poorer households, lower castes, women and femaleheaded households (Kabeer and Murthy 1997).

\subsection{The BRAC response}

In response to these gaps, which were particularly prevalent in Bangladesh, Bangladesh Rural Advancement Committee (BRAG) experimented with a development intervention that focused upon extremely poor, female-headed households. Extremely poor people, they realised, do not move along a continuum and escalate out of poverty. Rather, they oscillate into and out of poverty, and therefore need diverse income sources and safety nets to be able to cope with shocks. Through their Targeting Ultra Poor (TUP) intervention, they focused upon reversing what Devereux refers to as the three elements of destitution: meeting minimum subsistence needs, accessing key productive assets, and ending their dependence on transfers (Devereux 2003).

Upon carefully targeting the extreme poor, TUP beneficiaries receive a small cash stipend to help them meet their consumption needs; a productive asset so they can begin generating their own income; access to health services, as health shocks are often the greatest drivers of poverty; and complementary services such as skills and social development training, weekly hand-holding support by field staff, veterinary support, and linkages with local elite who act as a vertical social network. TUP beneficiaries receive this set of inputs for a total of 18 months, with the end goal of transitioning them out of extreme poverty and into a sustainable livelihood.

Impact assessment results of BRAC's TUP programme have been overwhelmingly positive. As compared to the control group, TUP beneficiaries purchased more productive assets (land, rickshaws, vans, and boats); enrolled their girls in primary school; have a much higher level of savings; and tend to use cash loans for income generating activities rather than for crisis coping (as the case for control group households) (Rabbani, Prakash and Sulaiman 2006).

Given these impacts, other civil society organisations around the world have been eager to follow suit. Noting this interest and the potential that such an initiative could have upon global extreme poverty levels, CGAP and the Ford Foundation spearheaded the 'global graduation 
Figure 1 Hypothesised pathway out of poverty

\begin{tabular}{|c|c|c|}
\hline $\begin{array}{l}\text { Outputs: } \\
\text { Ideal assets for members } \\
\text { Protection for assets } \\
\text { Income generation } \\
\text { Financial independence } \\
\text { Increase awareness of } \\
\text { government resources } \\
\text { Improve social behaviour } \\
\text { and health }\end{array}$ & $\begin{array}{l}\text { Process: } \\
\text { Targeting } \\
\text { FA training } \\
\text { Centre meetings } \\
\text { Individual household visits } \\
\text { Health Field Assts (FAs) } \\
\text { and Health director } \\
\text { Centre leaders } \\
\text { Health magic shows }\end{array}$ & $\begin{array}{l}\text { Inputs: } \\
\text { Assets } \\
\text { Buffalo insurance } \\
\text { Veterinary healthcare } \\
\text { Savings scheme } \\
\text { Stipend } \\
\text { Financial education } \\
\text { Field assistance } \\
\text { Health education }\end{array}$ \\
\hline
\end{tabular}

programmes'. As a part of this initiative, they partnered with nine local organisations in seven countries ${ }^{1}$ to adapt BRAC's methodology to their own contexts. The foundation of the intervention remains the same: increased consumption, improved health access, income generation, and awareness creation. Each beneficiary is also assigned a 'field assistant' whose role is two-fold: to help develop their productive skills and monitor their progress, as well as expand their time horizons by creating milestones for the future. The remit is to build promotional ladders by enhancing income generation, as well as to provide social safety nets by ensuring adequate access to food, healthcare, and moral support.

SKS is one of the nine pilot programmes being implemented in the Telangana region of Andhra Pradesh, India. The programme has successfully penetrated the microfinance market, yet through its 12 years of operation, SKS learned that their solidarity lending programme effectively excluded the poorest within the communities in which they worked.

In response, SKS initiated the Ultra Poor Programme (UPP). The UPP is geared towards those who do not meet the inclusion criteria for microfinance - in essence, those whom SKS classifies as the poorest. The package of inputs was extended to 426 women over an 18-month period (October 2007-June 2009).

The purpose of SKS's Ultra Poor Programme is to create sustainable livelihoods so that the extremely poor can graduate into one of two paths:

- Join an existing microfinance programme in the area (for the few that are strong enough to integrate into mainstream microfinance)

- Continue saving in groups and use their savings to strengthen and diversify their asset base (a viable transition for most).

\section{Process evaluation}

The UPP process evaluation responded to SKS' request for feedback in order to make programmatic modifications prior to scale-up. It took place at the midpoint of the pilot (July 2008 to December 2008), nine months into their 18month implementation. This evaluation does not seek to explain outcomes. Rather, it aims to provide an in-depth understanding of the processes of implementation from the perspectives of the UPP programme beneficiaries and SKS staff. As Figure 1 illustrates, processes refer to the mechanisms by which key inputs of the programme have been operationalised, and the means by which programmatic outcomes are achieved. This evaluation interrogates this pathway (Huda and Simanowitz 2009).

\subsection{Targeting}

Disaggregating the poor and identifying the most vulnerable is the foundation of the CGAP/Ford Foundation graduation programmes. A good targeting methodology is important, not just to ensure that the correct beneficiaries are selected, but to demonstrate a transparent and rational process to the community and external stakeholders. Initially, SKS identified a list of inclusion and exclusion criteria that beneficiaries must fulfil in order to qualify for the programme (Table 1). These indicators were the opposite of those used to select SKS microfinance clients. While microfinance clients were selected based on creditworthiness and economic 'activeness' (e.g. existing entrepreneurial abilities, a household guarantor who could help with repayments, and the self-confidence to take a loan), UPP members were chosen because they lacked these characteristics. 


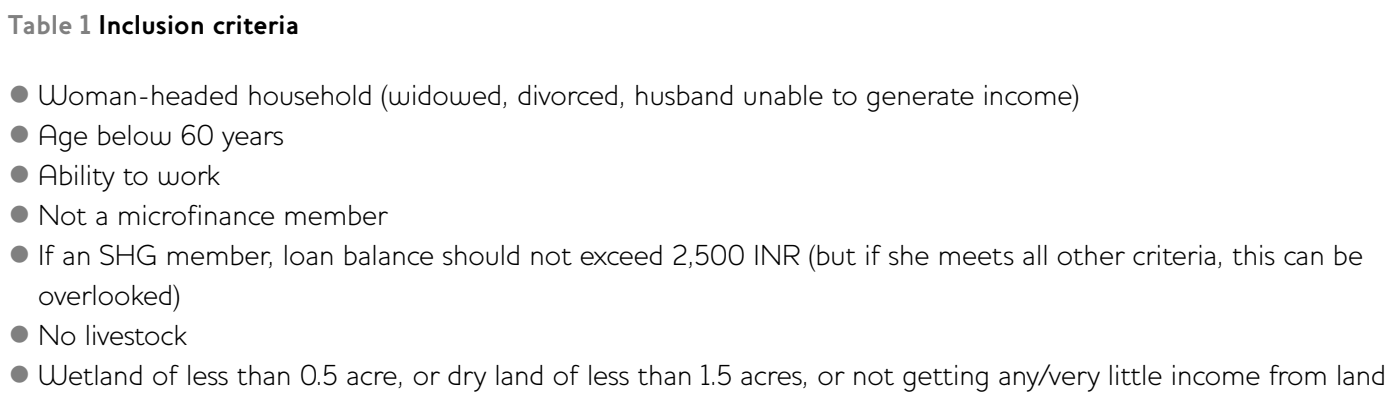

Objective criteria such as these are necessary for standardisation and scalability. SKS required a set of simple and easily verifiable indicators that every branch office could use in order to keep the selection process manageable when reaching a large number of people in varied locations around the country. However, poverty is contextualised depending on area, and these sensitivities need to be accounted for. Relying solely on objective indicators leads to decisions that are free of nuance, and excludes the community from the selection process. SKS therefore also drew upon community perceptions of poverty through a wealth ranking exercise, where local villagers identified those whom they felt were the poorest in their communities. This brought a localised understanding of extreme poverty to the initiative, while securing community buy-in. Staff, whose unique perspective combines both local and programmatic notions of poverty, made the final decisions through home visits and communal discussions. Taking from BRAC's targeting approach, SKS feels that by leveraging indigenous and programmatic knowledge, and triangulating between participatory and survey tools, they are able to narrow down the poorest more effectively (Matin and Halder 2004).

A few important lessons can be drawn from this targeting approach. First, SKS has appropriately implemented their targeting methodology and selected members based on their inclusion/exclusion criteria. ${ }^{2}$ According to the baseline survey results, ${ }^{3} 89$ per cent of members are widowed/abandoned; 86 per cent had no livestock prior to joining the UPP programme and 62 per cent owned no agricultural land. Case studies and focus group discussions (FGDs) also reconfirm this selection profile, where every member interviewed had no male household counterpart; had less than an acre of cultivable land and no-one possessed any livestock at the time of joining the programme. Second, SKS UP staff have simple and relevant inclusion criteria, which will facilitate their scale-up process. Having only two products, UPP and microfinance lending, helps programme staff easily identify potential UPP members, as the targeting criteria contrast with each other.

Conceptually, however, the targeting approach is based on a static notion of poverty. Those who are extremely poor today would be captured, but not those who become poor tomorrow. As SKS continues to scale to new sites and branches, there is little scope to return to original areas and bring the 'new poor' into the folds of the programme. Similarly, those who are targeted as extremely poor may have faced a sudden recent decline, but if one were to target them six months before or after, their situation would appear very different. Targeting methodology that captures 'snapshots' and does not consider the factor of time and the dynamic nature of poverty is not unique to SKS or the graduation programmes. Most development interventions that seek out beneficiaries, rather than having individuals apply to gain access to the programme (as with pro-poor government initiatives), rarely revisit areas once implementation has occurred.

\subsection{Design and delivery}

SKS's inputs were well conceptualised as part of the service delivery design - these include the assets, stipend, field assistant interface, health assistant interface and training. Learning from BRAC, SKS has combined both protective and promotional elements to ensure a holistic approach.

During any pilot programme, a number of unexpected issues arise which call for modification of inputs and alterations in strategy. This is especially true for the extreme poor, who 
may face unanticipated constraints. The key is to be responsive to these constraints, but to keep programmatic modifications to a minimum. A programme that is highly customised and continues to 'add on' inputs and respond to every individual need drives up programme costs. For a programme to be manageable and easily replicated, a certain level of standardisation is required.

SKS has maintained this balance. They have made a few of the following modifications in response to needs that arose during the course of the pilot:

- Due to inefficiencies in government health services, SKS hired a Health Director to treat beneficiaries, train field assistants and SKS health workers. Beneficiaries complained of government health services being far away, thus incurring high transport costs; government hospital staff discriminated against their socioeconomic status; and doctors were not available when emergencies occurred at night. SKS felt they needed to respond to this gap, and thus increased the capacity of their staff to respond to illnesses and health emergencies.

- Since the programme cannot fund major health emergencies, they encouraged members to set aside at least Rs10 at each meeting to act as their own personal health fund. The motivation was to create a buffer against health emergencies so members would not be compelled to sell off assets or fall into debt.

- With the increase of rice prices, members were encouraged to begin a 'rice saving scheme', which involved saving a handful of rice in a communal pot every day. A member can take from the community rice store when in need and replace the amount taken.

SKS did not significantly drive up their costs with these modifications. They stayed true to their initial design of inputs in order to maintain costeffectiveness, programmatic discipline, and a focus upon livelihoods promotion. By sticking to core inputs, SKS has created a model that is affordable, replicable and scalable.

\subsection{Stipend design}

SKS has a unique perspective on the use of stipends. The traditional view (adopted from
BRAC's TUP programme) is that the procurement of assets will force members to devote less time to daily wage labour (their primary means of income prior to joining the programme), and thus they need financial support to offset this income loss. SKS encourages members to continue their daily wage labour, while simultaneously taking care of their assets - this way, the assets will boost their existing income rather than replace it.

With this conceptualisation, members do not need a stipend to offset income losses. SKS also firmly believes that regularly distributing money to members creates a dependency upon this handout, thus creating resentment once the stipend ends. Taking what they believe to be a more 'empowering' approach, SKS informed members that if they are unable to pay for animal fodder for a particular week, SKS will assist them with the stipend. They are strict on the stipend being used towards the asset, and not for consumption - a drastically different approach from BRAC and the other graduation pilots that insist that the stipend is essential in ensuring food security.

There was initial scepticism as to whether the stipends were actually used towards livelihoods, as money is fungible and can be used towards anything. However, three months of data on stipend use illustrated that stipends are utilised 100 per cent of the time towards assets (e.g. animal fodder, stock for kirana shop owners, sewing needles/thread for tailors, pesticides/ fertilisers for those in land cultivation, etc.) Case studies reaffirmed this finding, as one member stated:

I took Rs300 two weeks ago to buy fodder for my buffalo. Right now it is hard to find fodder in the fields, and it is very expensive in the markets. The Rs300 were not enough, I still had to take out Rs500 of my savings to purchase the fodder.

When asked if she had saved part of the stipend or used it towards anything else, she exclaimed,

How is that possible? Fodder costs more than the stipend, so how can I save it or use it for anything else?

Although members are not spending their stipend on consumption, interviews illustrate that they have increased their expenditure on 
food items, which appears to be the result of greater household income due to their productive assets. This is a tremendous learning for all the pilots, and challenges the conventional notion that members need monetary assistance to boost their consumption levels.

The majority of members had also requested their stipend once, and about 20 per cent of members had never requested a stipend because they 'never needed one'. This differs from other graduation pilots where members are given weekly consumption stipends, and many requested extensions upon the stipend period terminating.

SKS's system behind the stipend is programmatically cost-effective, and does foster independence on behalf of the members. It must be considered, however, that this use of the stipend is context-specific. SKS members in the Telangana region benefited from daily wage labour schemes through the government, reducing their need for an alternative source of daily income. In contexts where employment opportunities are more scarce, the consumption stipend is necessary to boost consumption levels. It should also be noted that graduation pilot beneficiaries elsewhere demonstrated a tremendous amount of creativity when they were given cash stipends and the freedom to use it towards anything. Members in the Haiti pilot, for instance, took part of their stipend and saved it in a rotating savings group - when it was their turn at the lump sum, they used it diversify into small side businesses.

\subsection{Livelihood choices}

Building productive assets is one of the most important aims for UPP. Assets are intended to provide regular and reliable daily income (to overcome the insecurity of daily living) as well as longer-term income (for savings against the future and security in times of hardship).

Prior to joining the programme, UPP members had a lack of productive assets and asset savings. The fragility of their sources of daily income undermined their ability to accumulate assets for the future. Lack of assets meant they were less resilient against shocks and vulnerabilities.

SKS promoted asset development through the following strategies:
- Allowing members to choose any viable asset that had market potential

- Intensive training prior to receiving the asset and refresher courses

- Constant staff support and advice.

Table 2 provides a staff analysis of the risks, benefits and characteristics of who would benefit from each asset choice.

Through these various experiences with the above assets, SKS has drawn up some key lessons:

- Need for short- and long-term income: An important learning through BRAC is the need for both a short-term asset that can bring dayto-day income after the stipend ends, and a long-term asset that can act as savings against future expenses. Most graduation pilots offer two assets to achieve this dual purpose. SKS' strategy has been either to provide one asset that serves both purposes (e.g. a pregnant buffalo, where its milk can be sold daily as a regular source of income, while the buffalo and its offspring act as the long-term income source). Alternatively, members are encouraged to continue their daily labour as a regular source of income, and they are given only a long-term asset (e.g. land for cultivation, goats, etc.). SKS's strategy is economical, as they do not have to invest in two asset types per beneficiary; the focus on daily wage labour means that assets can be treated as an income boost rather than an income replacement; members are not given an excuse for discontinuing their current livelihood source and relying solely on programme benefits.

- Need for more guidance in identifying potential enterprise risks: Members are not always able at the beginning to think of all of the factors that influence success in an enterprise. In some instances, where a member's caste or community are all engaged in a certain enterprise, it makes sense for them to stick to what they know. But as one member who took donkeys stated,

If I took a buffalo my community would be fine
with it. But everyone in my caste has donkeys so I
selected it. It doesn't bring me that much income -
if I realised then how profitable buffaloes are, I
might have picked that over donkeys. I didn't know.




\begin{tabular}{|c|c|c|c|c|}
\hline Asset & $\begin{array}{l}\text { Characteristics of members } \\
\text { that choose this asset }\end{array}$ & $\begin{array}{l}\text { Pre-existing skills } \\
\text { needed? }\end{array}$ & Risks? & Benefits? \\
\hline $\begin{array}{l}\text { Buffalo } \\
\text { (pregnant) }\end{array}$ & $\begin{array}{l}\text { need for daily income } \\
\text { (does daily labour) } \\
50 \text { years or younger (needs } \\
\text { physical strength) } \\
\text { access to wastelands for } \\
\text { fodder } \\
\text { enough space within the hous } \\
\text { confidence in buffalo rearing } \\
\text { need neighbour/relative } \\
\text { support }\end{array}$ & $\begin{array}{l}\text { experience with } \\
\text { buffalo rearing } \\
\text { se } \\
\text { g }\end{array}$ & $\begin{array}{l}\text { - need for fodder } \\
\text { everyday } \\
\text { - requires space } \\
\text { need to purchase } \\
\text { fodder in rainy season } \\
\text { - must build a cattle } \\
\text { shed ( } 300 \text { INR) }\end{array}$ & $\begin{array}{l}\text { daily income/milk } \\
\text { household income } \\
\text { from manure/own use } \\
\text { milk for family/ } \\
\text { children } \\
\text { income from calves } \\
\text { social status of having } \\
\text { buffalo }\end{array}$ \\
\hline $\begin{array}{l}\text { Goats } \\
\text { (pregnant) }\end{array}$ & $\begin{array}{l}\text { no need for immediate } \\
\text { income } \\
\text { limited space outside, } \\
\text { more space indoors } \\
\text { physical strength } \\
\text { confidence with animals } \\
\text { - support from others } \\
\text { access to grazing area }\end{array}$ & $\begin{array}{l}\text { experience with } \\
\text { goat rearing }\end{array}$ & $\begin{array}{l}\text { requires grazing } \\
\text { goats are susceptible } \\
\text { to disease } \\
\text { kids are easily eaten } \\
\text { by wolves/dogs and } \\
\text { die of disease } \\
\text { theft } \\
\text { frequent miscarriages } \\
\text { won't give regular } \\
\text { income } \\
\text { indoed to lock them }\end{array}$ & $\begin{array}{l}\text { cheaper to feed than } \\
\text { buffalo (only graze on } \\
\text { leaves, cheaper to buy } \\
\text { grass if not available, } \\
\text { than fodder) } \\
\text { - delivers calves } 2 \times \text { a } \\
\text { year, each time up to } 3 \\
\text { kids } \\
\text { substantial income } \\
\text { from selling goats, easy } \\
\text { to build a herd } \\
\text { can use manure, sell it }\end{array}$ \\
\hline Land lease & $\begin{array}{l}\text { investment capacity } \\
\text { no need for immediate } \\
\text { income } \\
\text { more risk-taking } \\
\text { strength to work on land }\end{array}$ & $\begin{array}{l}\text { experience with } \\
\text { cultivating land } \\
\text { knowledge of crops } \\
\text { and harvesting }\end{array}$ & $\begin{array}{l}\text { crop damage } \\
\text { - labour costs } \\
\text { risk of rain or } \\
\text { drought } \\
\text { - delayed income } \\
\text { high-risk venture }\end{array}$ & $\begin{array}{l}\text { food security } \\
\text { highest income/ } \\
\text { biggest risk } \\
\text { can diversify and use } \\
\text { as grazing land/fodder } \\
\text { ability to work in own } \\
\text { field }\end{array}$ \\
\hline $\begin{array}{l}\text { Kirana shop } \\
\text { (small } \\
\text { trade) }\end{array}$ & $\begin{array}{l}\text { more confidence required } \\
\text { than other assets } \\
\text { comfortable with money } \\
\text { basic arithmetic skills } \\
\text { surrounded by lots of } \\
\text { houses } \\
\text { strong social networks to } \\
\text { build clientele } \\
\text { active sellers already }\end{array}$ & $\begin{array}{l}\text { knows how to sell } \\
\text { business experience } \\
\text { basic accounting } \\
\text { skills }\end{array}$ & $\begin{array}{l}\text { - selling on credit } \\
\text { items may spoil } \\
\text { more risk of failure, } \\
\text { business not insured } \\
\text { like livestock } \\
\text { easy to deplete } \\
\text { stock for personal use } \\
\text { requires a lot of FA } \\
\text { supervision } \\
\text { more than } 12 \text { hours } \\
\text { work }\end{array}$ & $\begin{array}{l}\text { - can do other side } \\
\text { businesses (e.g. making } \\
\text { bidis, purchase goats, etc.) } \\
\text { gives daily income } \\
\text { - high potential for } \\
\text { profitability } \\
\text { can stay at home with } \\
\text { small children } \\
\text { - less physical labour } \\
\text { required } \\
\text { can purchase household } \\
\text { goods from own shop } \\
\text { ability to save more }\end{array}$ \\
\hline $\begin{array}{l}\text { Others (e.g. } \\
\text { tailoring, } \\
\text { vegetable } \\
\text { vending, } \\
\text { etc.) }\end{array}$ & $\begin{array}{l}\text { has caste-based skills } \\
\text { uncomfortable with } \\
\text { livestock } \\
\text { can manage asset with } \\
\text { limited supervision/assistance }\end{array}$ & $\begin{array}{l}\text { - technical skills } \\
\text { already }\end{array}$ & - limited FA support & $\begin{array}{l}\text { can devote less time } \\
\text { no need to learn a } \\
\text { new skill }\end{array}$ \\
\hline
\end{tabular}

FA, field assistant. 
FGD results showed that a shop owner and a restaurant owner were least happy with their assets. They did not have previous business experience, and such enterprises are challenging. As with most enterprises that involve selling on credit, their biggest problem was re-collecting the money from customers. When asked why they chose this enterprise, they said they did not want livestock, and their field assistant (FA) gave them this opportunity as it sounded interesting. At the same time, another shop owner had diversified with the help of her FA. When asked about her success, she stated that she only pays wholesalers after she has collected everything back from those who took credit. She had previous business experience and confidence. They all received appropriate advice from their FA, but they joined the programme with different pre-existing skill sets. Selecting the proper asset is the essence of livelihood strategy, and must involve more than interest in an idea. FAs must honestly ask themselves, 'can this member succeed in doing this?' The characteristics presented in Table 2 should be considered when matching assets to skill sets.

\subsection{Field assistant interface}

The concept that underlies the Ultra Poor programme is that extremely poor women require more than financial or technical inputs, and need close support in developing the skills and confidence to effectively utilise these resources. Poverty is not just a lack of money, but a set of interconnecting physical, social and psychological weaknesses. The role of the field assistant is to accompany members out of poverty. This entails helping them to boost their real income, but also developing their imaginations, sense of agency (Kabeer 2002) and capability to aspire (Appadurai 2004). These are important resources that human beings draw upon in their efforts to fulfil their present needs and imagine a better future for themselves and their children.

Field assistance involves a combination of encouragement, instilling discipline, education and providing access to resources. They provide the following support to ultra poor members:

- Weekly centre meetings and household visits

- Classroom livelihoods trainings

- Health education and messaging on pertinent social issues
Regular entrepreneurial advice and handholding

- Goal-setting and a plan to reach the goals by the end of the programme

- Foster autonomy by weaning members off programmatic inputs

- Encourage and foster the use of government resources

- Formal financial education.

The FAs have a standardised approach to service delivery - their centre meetings all have the same components and order, and trainings are all conducted in a similar fashion. They deliver the same social messages, using the same types of mechanisms (games, flip charts, etc.) There is little room for individual creativity and ad hoc assistance. Microfinance operations typically identify this regimented client/staff approach as an important element of programmatic success (Hashemi 2006).

Field assistants are teachers of ultra poor members. Members do not necessarily see FAs as a 'friend' whom they can confide in, as FAs keep household visits brief. SKS senior staff have said this is intentional to avoid emotional dependence, as FAs will no longer support members once the programme ends. According to the members, they see the FA as a 'guru' whom they respect and have learned from.

Members also unanimously gave credit to FAs for their pivotal role in shaping their livelihood visions and goals. FAs took the critical step of establishing goals with members, and helping them build and grow their businesses. A kirana shop owner proudly recounted her plans to start selling clothing in her store - with the advice and help of her FA. Another member claimed that she is currently getting Rs6 per litre of buffalo milk from the nearby market, but her FA is working on aggregating the milk supply of all members so that they can start selling to a milk distribution centre for higher profits. The idea and implementation of a milk cooperative exemplifies the dedication, innovation and commitment of FAs to help members thrive with their livelihoods.

\subsection{Financial education}

SKS offers a well-designed, rigorous financial education module for members to learn basic money management skills. Financial education is not a standard input for BRAC or the other 


\begin{tabular}{ll}
\hline Figure 2 Income and expenditure survey & \\
\hline Income & Expenditure \\
\hline Cash in hand & Expenditure on enterprise \\
Members' income from daily wages & Food and consumption items \\
\hline Other family members' income & Health and medical expenditure \\
Income from the enterprise & Expenditure on other general items \\
\hline Income from SKS grant/allowance & Credit/hand loan repayments \\
Income from credit/hand loans & Travelling cost \\
\hline Other income & Misc. exp. \\
Total income & Total expenditure \\
\hline & Members' weekly savings \\
& Balance cash in hand \\
\hline
\end{tabular}

graduation pilots, but given SKS's focus upon income generation and sustainability, the strategy makes sense.

The module covers the following areas: income and expenditure tracking, budgeting, financial goal-setting and financial negotiations.

In the income and expenditure tracking, FAs collect information such as that presented in Figure 2.

FAs then analyse the data and share the results with members. As an FA stated, 'we can appreciate how hard it is to cut down expenditure and maximise income, but we know that our members will continue to suffer unless they make these financial changes.'

Each meeting focuses upon a particular member to ensure that the training is practical and relevant. In the financial goal-setting module, for example, the member of that week is asked to show with rocks, the number of assets she has now, the number she wants to have at the end of this programme, and explain how she plans on reaching that goal. She is given fake money to make transactions, while the other members watch.

Members all claim to enjoy the financial education module, and as a result of the goalsetting exercise, members have also been able to articulately explain where they want their livelihoods to be at the time of graduation. At baseline, members' time horizons were limited and most were unable to look past the prospect of feeding their children for the next few days. The following statements show how their time and visual horizons expanded:

I have two goats now. I want to grow my herd - by the time this programme finishes, I hope I'll have six or seven goats. I will keep the female ones so my herd will grow, sell the male ones to buy more females. With a big goat herd, I will never have to worry about money.

I currently have a plot of land where I grow lentils. If I have a good harvest, I can make up to Rs7,000. With that money, I will reinvest and purchase another plot of land and grow another variety of lentil. I will keep reinvesting in land - I don't know how to raise animals, but I know that with the profits from two plots of land I will be in a good position when I graduate.

Despite these advances, the various idiosyncratic and life cycle shocks that UP members face (health shocks, dowry expenses, etc.) force them to take on debt as a crisis coping mechanism. They are not resilient enough to rely on their assets or savings, and this element of their poverty trap has not been effectively dealt with by the programme. Many members borrow against their group interest-free and pay back slowly, and if the group savings cannot meet their needs, FAs encourage members to borrow from government self-help groups at 1 per cent interest. Although advice is given to reduce members' reliance upon money lenders who 
charge extortionate interest rates, members feel there is a strong need for a module that properly teaches them how to manage debt.

\section{Discussion: who graduates and why}

Upon completing the UPP programme, an internal graduation assessment indicated that 95 per cent of members were ready to graduate out of extreme poverty and into a sustainable livelihood. SKS used the following criteria to determine graduation eligibility:

- Multiple sources of income

- Savings of at least Rs800

- Adequate food, shelter and clothing

- At least one month's rice supply

- Awareness and ability to access government services (health, pro-poor benefits, etc.)

- Ability to maintain or expand their livelihood (through savings scheme, microfinance loan or government self-help group).

SKS rendered that 405 women were able to graduate from UP by fulfilling this criteria, while 21 were unable to graduate. This highlights an issue that requires further discussion: although everyone was given the same set of resources and inputs, why is it that some managed to succeed while others did not?

Qualitative interviews help us to understand that idiosyncratic traits may go a great deal towards explaining why some poor women are more able than others to take advantage of the emerging opportunities provided to them. Those that did not graduate shared some of the following characteristics:

- Lack of personal agency and motivation to improve their trajectory

- Exposure to serious health shocks drained these members of household resources, and in several cases, left them bereft of a household income earner

- High number of dependents to earners: the weakest members lacked other income earners within the household, and were forced to support many dependents on their meagre earnings

- Environmental shocks, specifically droughts, that ate into members' agricultural gains.

The oscillating nature of poverty must also be considered, as SKS is evaluating members' performance based on a static snapshot. In some instances, a health or environmental shock eroded a members' gains temporarily, but they may have had the resilience to overcome these setbacks post-programme. Similarly, those who graduated may not be able to sustain these gains - one would need to revisit them in the future to see if they were able to maintain this progress. Although members are evaluated at a point in time, much like students sitting for a final exam, the results cannot tell us if members have definitively 'graduated' out of extreme poverty. At the most, they give us a benchmark of what members have been able to achieve upon receiving 18 months of programmatic support. What we can say with certainty is that over the course of 18 months, the majority of UPP members developed sustainable livelihoods with some safety nets in place.

\section{Conclusion}

This article has attempted to uncover why the graduation programme targets the poorest more rigorously and delivers upon the tenets of a social protection agenda more effectively than state run poverty alleviation schemes.

Given the findings explored here, is the graduation scheme in India an effective response to extreme poverty that the state should adopt and implement? Engaging with the state will enable this initiative to reach masses of the extreme poor rather than simply pockets, and according to the Director of SKS, 'it will be difficult for this programme to reach its maximum potential without involvement from the state'.

This desire for accuracy is evident throughout SKS's implementation, but is absent in the government's approaches to poverty alleviation. Although SKS is regimented and believes in standardising processes, they also customise some inputs to contextual specificities. For instance, SKS is now expanding the graduation model to Orissa, but are first extensively researching which livelihoods could flourish in this forest-based, tribal context. There are no daily wage labour schemes in the remote region where the programme is being implemented, so the stipend and assets must be re-conceputalised to meet the gap for short-term income. SKS is driven by their organisational belief that properly matching livelihood choices to skill sets is the basis for programmatic success. With top- 
down government programmes, that same attention to detail is lost.

However, would SKS be able to maintain this level of responsiveness when scaling-up to millions, and will it ever have the resources necessary to do so? The state can effectively scale, but would the crucial element of handholding disappear? Would the model get stripped of its personal touch and turn into another bareboned asset distribution scheme?

\section{Notes}

1 The pilots are in the following countries: Honduras, Peru, Haiti, India, Pakistan, Yemen and Ethiopia.

2 It is beyond the scope of this evaluation to determine whether these members are in fact the poorest - this would require a comparison of UPP members with MFI clients, as well as

\section{References}

Appadurai, A. (2004) 'The Capacity to Aspire: Culture and the Terms of Recognition', in V. Rao and M. Walton (eds), Culture and Public Action, Stanford: Stanford University Press

Banerjee, A.; Duflo, E.; Glennerster, R. and Kinnan, C. (2009) The Miracle of Microfinance? Evidence from a Randomized Evaluation, Centre for Microfinance Working Paper 31, Tamil Nadu: Centre for Microfinance, Institute for Financial Management and Research (IFMR)

Devereux, S. (2003) Conceptualising Destitution, IDS Working Paper 216, Brighton: IDS

Hashemi, S. (2006), Graduating the Poorest into Microfinance: Linking Safety Nets and Financial Services, CGAP Focus Note 34, Washington DC: Consultative Group to Assist the Poorest (CGAP)

Hashemi, S. (1997) 'Those Left Behind: A Note on Targeting the Hardcore Poor', in Geoffrey Wood and Iffath Sharif (eds), Who Needs Credit? Poverty and Finance in Bangladesh, Dhaka: The University Press Limited

Huda, K. and Simanowitz, A. (2009) 'A Graduation Pathway for Haiti's Poorest: Lessons Learnt from Fonkoze', Enterprise Development and Microfinance 20.2, London: Practical Action Publishing

Kabeer, N. (2002) 'Resources, Agency, Achievements: Reflections on the Measurement of Women's Empowerment',
A potential way forward could be the marrying of methods between the state and civil society. The state has the ability to effectively scale, while the NGO has a client-driven ethos. Perhaps the NGO can implement with resources provided by the state, or the government staff can be trained by the NGO on how to keep the varied needs of the extreme poor at the forefront of their strategy?

others in the community who are not part of this programme.

3 The baseline survey was conducted by the organisation implementing the randomised control trial for SKS' UPP programme. The process evaluators drew upon the survey results to triangulate qualitative findings.

Development and Change 30.3, The Hague: International Institute of Social Studies Kabeer, N. and Murthy, R.K. (1997) Compensating for Institutional Exclusion? Lessons from Indian Government and Non-government Credit Interventions for the Poor, IDS Discussion Paper 356, Brighton: IDS

Matin, I. and Halder, S. (2004) Combining Methodologies for Better Targeting the Extreme Poor: Lessons from BRAC's CFPR/TUP Programme, Dhaka and Ottawa: BRAC and Aga Khan Foundation Canada

Mooji, J. (2003) Smart Governance? Politics in the Policy Process in Andhra Pradesh, India, ODI Working Paper 228, London: Overseas Development Institute

Pellissery, S. (2005) Process Deficits or Political Constraints? Bottom-up Evaluation of Noncontributory Social Protection Policy for Rural Labourers in India, CPRC Working Paper 54, Oxford: Chronic Poverty Research Centre, University of Oxford

Rabbani, M.; Prakash, V. and Sulaiman, M. (2006) Impact Assessment of CFPR/TUP: A Descriptive Analysis Based on 2002-2005 Panel Data, CFPR/TUP Working Paper 12, Dhaka and Ottawa: BRAC and Aga Khan Foundation Rahman, A. and Razzaque, A. (2000) 'On Reaching the Hardcore Poor: Some Evidence on Social Exclusion in NGO Programmes', The Bangladesh Development Studies 26.1: 1-35 